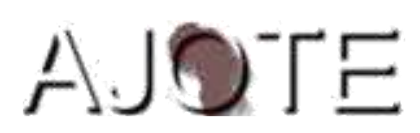

African Journal of Teacher Education

ISSN 1916-7822. A Journal of Spread Corporation

Volume $9 \quad 2020 \quad$ Pages $152-174$

\title{
Student-Teachers' Experiences and Strategies of Managing Disruptive Behaviours in Tanzania Secondary Schools
}

\author{
William Pastory Majani \\ Educational Psychology and Curriculum Studies \\ Dar es Salaam University College of Education (DUCE) \\ Tanzania
}

\begin{abstract}
This paper reports on student-teachers' experiences during a six-week teaching practicum of disruptive classroom behaviours by students in selected Tanzanian secondary schools and the strategies that the student-teachers employed to manage them. Questionnaire and semi-structured interviews were employed to collect data from 70 student-teachers. Using qualitative thematic analysis and descriptive quantitative analysis strategies, it was revealed that student-teachers did very little to enhance appropriate classroom behaviours. Instead, they relied on punitive strategies such as punishment to deal with disrupting students. Reliance on punitive measures limited their ability to use positive feedback, tolerance and relational support strategies, which are regarded as more effective in fostering appropriate classroom behaviours by empowering students to take control of their own behaviour. These findings have important implications for teacher training programmes, and students learning. The paper concludes by asserting that like any other lessons, appropriate behaviours in classrooms need to be taught and nurtured not simply demanded.
\end{abstract}

Keywords: Disruptive behaviour, punitive and supportive strategies, Tanzania

\section{Background of the Study}

Classroom management and students' disruptive behaviours are considered major challenges that face student-teachers as well as experienced teachers (Ghazi, Shahzada, Tariq \& Khan, 2013; Wubbels, 2011). The ability to manage disrupting students is reported as a critical variable for effective teaching and classroom management (Matsoga, 2003; Njoroge \& Nyabuto, 2014; Närhi, Kiiski \& Savolainen, 2017 Semali \& Vumilia, 2016). However, scholarly evidence show that many 
pre-and in-service teacher programmes lack concrete strategies to equip student-teachers with competencies necessary to deal with students with different behavioural problems in the classroom (Ghazi, Shahzada, Tariq \& Khan, 2013; Stough, 2006;Woodcock \& Reupert, 2017; Wubbels, 2011). The deficit is the cause of both student- teachers and the experienced teachers reporting being overloaded by students' disruptive behaviours such as fighting in the classrooms, hostility, abusive language and bullying etc (Semali \& Vumilia, 2016). On the other hand, students complain about their teachers' aggressiveness and harsh punishments (Ghazi, Shahzada, Tariq \& Khan, 2013; Gibbons et al., 2018; Nene, 2013). They are of the view that teachers are too harsh, uncaring, and unfriendly (Mugabe \& Maposa, 2007; Nene, 2013). The deteriorating relationship between teachers and students rooted in poor management of disrupting learners makes learning challenging and non-inspiring (Vitto, 2003). Drawing on this backdrop, this study reports on student-teachers' experiences and the management strategies they employed to address classroom disruptive behaviours in selected Tanzanian secondary schools during teachers' preparatory practicum.

\section{Typologies of Classroom Disruptive Behaviours}

The literature indicates that disruptive behaviours in schools take many forms such as verbal abuse towards teachers, aggression, and students hurting others (Shavega, Tuijl \& Brugman, 2015). Disruptive behaviours also include personal attacks on teachers, students' noncompliance or refusing to follow instructions (Gibons et al., 2018; Shavega, Tuijl \& Brugman, 2015). They include speaking disruptively out of turn, threatening to physically harm teachers and fellow students, bullying and harassment. Hence, scholars have classified disruptive behaviours based on the degree of severity and the mode through which they manifest and are presented.

According to Levin and Nolan (1996), what commonly occurs during disruptive behaviours could be categorized into; a). verbal interruptions such as talking out of turn, name calling, humming and calling out, b). off task that includes daydreaming, tardiness, doodling and inattentiveness, c). disrespect that involves refusing directions, verbal aggressions and negligence and, d). physical movements such as wandering about, visiting other leaners and throwing objects around the classroom. Scholars regard these classroom behaviours to have a mild impact on teaching and learning. However, if left unattended, they tend to inhibit the normal flow of teaching and learning from occurring (Marais \& Meier, 2010; Nene, 2013; Woodcock \& Reupert, 2017). 
Classroom behaviours have also been categorized based on the consequences the behaviours bring to students, teachers, and the entire teaching and learning process. De Wet (2003), Mugabe and Maposa (2007); Nene (2013) and Rayment (2006), categorized the most serious disruptive behaviours to include; a). physical violence (e.g. fighting). b). bullying (e.g. name calling such as; stupid, fat, skinny or retarded and dispossessing fellow learners belonging). c). insubordination to teachers (e.g. cursing and threatening to harm teachers) and d). the use of drugs and other psychoactive substances. The latest classroom disruptive behaviours category takes the form of aggression via electronic media directed at both teachers and fellow students (Baker \& Tanrikulu, 2010; Kowalski \& Limber, 2007; Shapka, Onditi, Collie \& Lapidot-Lefler, 2018; Sharrif \& Jonny, 2007).

\section{Consequences of Classroom Disruptive Behaviours}

The landscape of teaching and learning is affected by classroom disruptive behaviours in many ways. The general literature agrees that students' disruptive behaviours pose enormous challenges not only to teachers but also to students and the teaching and learning process (Matsoga 2003); Njoroge and Nyabuto 2014; and O'Brennan, Bradshaw and Furlong 2014). They observe that disruptive behaviours affect learning in different dimensions (Cooperkline 2009; and Finn, Fish and Scot 2008). First, disruptive behaviours affect students' learning, reduces the possibility of their excelling in higher in education, and interferes with their progress and graduation. Second, they constitute a major source of stress and distraction to teachers and thereby contribute to teaching ineffectiveness (Browser \& Tomic, 2000; Hastings \& Bham, 2003; Oliver \& Reschly, 2007; Rose \& Gallup, 2005). Disruptive behaviours are leading causes of teachers' burn out and turnover (Ghazi, Shahzada, Tariq \& Khan, 2013; Mahvar, Farahani, \& Aryankhesal, 2018; Närhi, Kiiski \& Savolainen, 2017; Woodcock \& Reupert, 2017). The fear of dealing with disruptive behaviours are closely associated with why some novice teachers balk from joining the teaching profession after they have graduated (Sullivan, Johnson, Owen \& Conway, 2014; Yusoff \& Mansor, 2016). Third, disruptive behaviours consume both time and resources that should be channelled to learning (Walker, Ramsey and Grasham, 2004). In summary, disruptive behaviours waste teaching time, disrupt those students who are learning, threatens safety, overwhelms teachers and contribute to ruining students' chances of successful schooling and life (Walker, Ramsey and Grasham, 2004). These consequences call for immediate interventions (Vitto, 2003; Wubbels, 2011). Drawing on 
this understanding, this paper advocates for the need to have teachers with sufficient knowledge and skills to address disruptive behaviours more effectively. This is made possible if educators and policymakers capitalize on classroom management skills as core components in both pre-and inservice teacher programmes (Mahvar, Farahani, \& Aryankhesal, 2018; Sullivan, Johnson, Owen \& Conway, 2014; Wubbels, 2011).

\section{Categories of Classroom Management Strategies}

Student-teachers, as well as experienced in-service teachers, use various strategies to curb classroom disruptive behaviours. The strategies include those categorized as punitive; when teachers use punishment or reprimand (Stewart, 2004), use of threats and warnings (Tulley \& Chiu, 1995), detention and setting extra work (Reupert \&Woodcock, 2011). The second category of strategies is using non-verbal cues that include saying a students' name as a sign of warning (Atici, 2007; Bromfield,2006; Stough, 2001). A third category includes relational and supportive strategies such as the use of rewards and praise (Nene, 2013), effective feedback (Reupert \&Woodcock, 2011) and helping students develop self-regulation (Woodcock \& Reupert, 2017; Marais \& Meier, 2010). Of all the strategies employed to curb classroom disruptive behaviours, research shows little evidence that supports the use of punitive and authoritarian strategies (Osher, Bear, Sprague \& Doyle, 2010; Sullivan, Johnson, Owen \& Conway, 2014). Instead, scholars recommend strategies that are democratic and focused on fostering learners' self-regulation and meaningful student-teacher interactions (Mahvar, Farahani, \& Aryankhesal, 2018; Woodcock \& Reupert, 2017; Wubbels, 2011). These may include effective feedback, student-teacher mutual communication and interactions, clear and consistent classroom rules and expectations (Mahvar, Farahani, \& Aryankhesal, 2018; Närhi, Kiiski \& Savolainen, 2017). Despite many studies on the consequences of disruptive behaviour in teaching and learning particularly in the developed countries, little is known about strategies employed by student-teachers to address disruptive behaviours in the classroom especially during practicum in developing countries. Based on this background information and the knowledge gap highlighted above, this paper explores studentteachers' experiences and the strategies they employed to address disruptive classroom behaviour in Tanzania secondary schools. 


\section{Research Methodology}

Qualitative and quantitative research strategies were employed to study student-teachers' experiences and the strategies they employed to manage classroom disruptive behaviours. Data collection and analysis of the research employed qualitative and quantitative strategies involving semi-structured interviews and questionnaire. To analyse and interpret data in this study, thematic qualitative analysis was merged with descriptive quantitative analysis. Bryman (2016), Creswell (2015) Denzin and Lincoln (2013) and Stake (1995) referred to this approach as triangulation, viz., the use of more than one source of data to cross-check the trustworthiness of the findings (Bryman, 2016).

\section{Sample Size and Sampling Procedures}

The participants of this study included undergraduate and postgraduate student-teachers who practised teaching in four (4) secondary schools that had previously reported having many disrupting students. The sample included 18 in-service undergraduate student-teachers, 31 thirdyear students and 21 postgraduate student-teachers. This category of participants was purposely selected based on different criteria and assumptions. The in-service student-teachers were selected because they were considered to have had the necessary information and experiences required for this study. The inclusion criteria for this group was their experiences and the prior training they had undergone in the teaching profession. Their classroom teaching experience dealing with students' classroom behavioural problems was regarded as an additional key criterion for their inclusion in the study. Third-year student-teachers were selected for their experiences on matters relating to classroom interactions and classroom management acquired through apprenticeship and teaching practicums during their first and second years of undergraduate studies.

The postgraduate student-teachers included in this study were those who had prior teaching experiences before joining the university to upgrade their teaching qualifications. The recruitment of this group involved circulating a register to a whole class of postgraduate students-teachers to establish their prior experience in teaching. Those with prior experience in teaching and who were willing to participate were thus obtained for the study. Table 1 illustrates participant distribution. 
Table 1. Distribution of participants by degree programme

\begin{tabular}{lllll}
\hline Degree Programme & Sex & & Total & \% \\
& Female & Male & & \\
\hline Bachelor of Science & 9 & 7 & 16 & 22.9 \\
Bachelor of Science with Education & 9 & 6 & 15 & 21.4 \\
Bachelor of Arts & 8 & 5 & 13 & 18.6 \\
Bachelor of Arts with Education & 4 & 5 & 9 & 12.9 \\
Postgraduate Diploma in Education & 7 & 10 & 17 & 24.3 \\
Total & $\mathbf{3 7}$ & $\mathbf{3 3}$ & $\mathbf{7 0}$ & $\mathbf{1 0 0}$ \\
\hline
\end{tabular}

Source: Field data (March 2018)

\section{Data Collection and Analysis}

Questionnaire and semi-structured interviews were administered to the participants to seek their perceptions, opinions, and attitudes towards students' disruptive behaviours and what strategies they regarded as suitable in addressing behavioural problems. A total of 70 questionnaires were filled and handed back to the researcher for data analysis and interpretation. Data obtained through close-ended questionnaires were analysed descriptively (statistically describing, aggregating, and presenting the constructs of interest or associations between these constructs) (Bryman, 2016; Johnson \& Christensen, 2017). Percentages and frequencies were processed manually, systematically analysed and presented into percentages and frequencies to suit the research purpose.

The information generated through semi-structured interviews were coded, transcribed and analysed thematically in accord with Braun and Clarke (2006) and Joffe (2012)'s definition whereby thematic analysis involves sorting, discovering, interpreting and reporting patterns and clusters of meaning within the data. Findings from the semi-structured interview were further sorted, grouped into allied themes and units. This was followed by categorizing data into similar themes and subthemes for discussion and interpretations. In this paper, descriptive and thematic analysis strategies were integrated in discussing and interpreting findings in this study. 


\section{Research Findings}

\section{The Magnitude of Disruptive Behaviours in Selected Secondary Schools}

In order to understand the magnitude of disruptive behaviour in selected secondary schools, participants were asked how frequently they encountered disruptive behaviours during classroom instructions. The table below illustrates the magnitude of disruptive behaviours in selected secondary schools.

Table 2. Student -teachers' responses on encountering disruptive behaviours in the classrooms

\begin{tabular}{llc}
\hline Responses & Frequency & Percentage \\
\hline Always & 24 & 34.3 \\
Rarely & 28 & 40 \\
Not at all & 18 & 25.7 \\
\hline
\end{tabular}

Source: Field data (March 2018)

Findings from the questionnaire (Table 2) indicate that 28 (40\%) student-teachers reported that they rarely encountered disruptive behaviours in their classes. Whereas, 24 (34.3\%) reported to have always encountered disruptive behaviour in their classrooms. Eighteen participants (25.7\%) reported to have not encountered disruptive behaviour at all in their lessons. However, information from semi-structured interview contradicts the findings from the questionnaire. For example, during the interview sessions, seven (7) out of ten (10) participants who took part in semi-structured interview sessions agreed that they encountered many incidences of disruptive behaviours causing them to spend most of their time dealing with students' behavioural problems. The following excerpts illustrate further student-teachers' responses to the question, How frequent did you encounter disruptive behaviours in your lessons?

Table 3. Student teachers' extracts on encountering disruptive behaviour in the classrooms

\begin{tabular}{ll}
\hline Data extract & Emerging themes
\end{tabular}

I think, it is a common thing to all of us! You know with revolution in technology, students are difficult to manage. You find some students who illegally bring the phones with them in the classroom are text messaging, some are talking without asking permission from the teacher and [showing]
1. Disruptive behaviour is common

2. Usage of Phonestext messaging 
other unwanted behaviours. These interfere teaching in many ways (BSC- $3^{\text {rd }}$ year).

Always! There is no single day you can say I have not encountered a disruptive behaviour in my classroom, what I normally do is to punish the disruptive student before fellow students. This acts as a lesson to other disrupting students (BAED-3 ${ }^{\text {rd }}$ year).

Teaching is like parenting, students do differ. Therefore, you do not expect your classrooms to be calm every day. Today is calm but tomorrow chaos. Therefore, as a teacher I am prepared for every situation every day. What I do is to make sure students are all involved in the lesson (In-service teacher).
3. Side conversation

4. Teaching disrupted

1. Disruption is normal

2. Punitive measures

3. Compliance to classroom rules

1. Students behave differently

2. Supportive teacher(s)

3. On-task behaviour

Findings from both the questionnaire and semi-structured interviews indicate that many of the participants had encountered disruptive behaviours during classroom instructions. While the questionnaires disclosed that 18 participants $(25.7 \%)$ had not encountered disruptive behaviours at all, the findings from semi-structured interviews show that disruptive behaviour is a common feature in the selected secondary schools. While the findings from questionnaire and semistructured interviews understate the degree of disruptive behaviours in classrooms, they point out an important perspective concerning how the student teachers interpreted the current research. The contradiction is a reflection that student-teachers felt that if they reported frequently encountering disruptive behaviour, it could be interpreted as a sign of weakness and ineffectiveness in managing their classes. As Brouwer and Tomic (2000) and Friedman and Farber (1992) noted, teachers tend to ignore classroom disruptive behaviours to avoid burn out and protect their self-esteem. This suggests that student-teachers (indeed experienced teachers) tend to employ what Mahvar et al. (2018) referred to as avoidance strategies in order to deal with disrupting classroom behaviours. It can be deduced from this finding that the student teachers believed that ignoring the unwanted behaviour will eventually make it disappear. However, ignoring the problem as a classroom 
management strategy remains debatable among scholars and researchers in education and social science (Booth, 2017; Brandon et al., 2014).

Overall, data collected through questionnaire and semi-structured interviews suggest that disruptive behaviours are evident in many classes of the secondary schools composing the sample of this study.

\section{Different Types of Disruptive Behaviours and their Severity}

Data generated through questionnaire and semi-structured interviews indicate that common disruptive classroom behaviours in Tanzania schools range from mild to dangerous ones. The findings of this study revealed that within the period of their six weeks practicum, student-teachers experienced and dealt with different disruptive behaviours that ranged from classroom side conversations to bullying and aggressive or offensive comments addressed to them and to fellow students. The table below indicates student-teachers' responses in a questionnaire about common disruptive behaviours they encountered in the classrooms.

Table 4. Common classroom disruptive behaviours reported by student-teachers

\begin{tabular}{ll}
\hline Disruptive behaviour & \# Instances reported \\
\hline Bullying & 9 \\
Text messaging & 8 \\
Abusive language towards teachers & 5 \\
Students fighting one another & 7 \\
Side conversation & 17 \\
Personal attack to the teacher & 9 \\
Students leaving classrooms without permission & 13 \\
Noncompliance & 12 \\
Student speaking without permission & 10 \\
Making offensive comments to the teacher & 6 \\
Constant disagreeing with the teacher & 5 \\
Students dominating and monopolizing the discussion & 4 \\
\hline
\end{tabular}

Source: Field data (March 2018) 
Table 4 indicates that the participants reported instances of side conversation, students leaving classrooms without permission and students' non-compliance with instructions as the most recurrent disruptive behaviours in their classrooms. This was followed in terms of recurring frequencies by the problems of students speaking without permission and bullying fellow students. These findings suggest that many of the reported disruptive instances fall under the category of mild or common occurring classroom behaviours (refer Levin \& Nolan, 1996). However, instances of bullying (7), fighting (6) and aggressive or offensive comments directed to teachers and fellow students (6) signal the presence of severe or seriously disruptive behaviours in Tanzanian secondary schools. As a way to triangulate findings, I asked student-teachers in an interview to describe the nature of students who are most likely to be involved in disruptive behaviours that they highlighted in the questionnaire and some participants mentioned age, gender, class level and students' subject mastery or capability as critical variables. The following excerpts illustrate further:

Table 5. Student-teachers 'opinions on different types of disruptive behaviours and their severity

\section{Data extract}

In my class, I do not see many girls misbehaving like what boys do" (in-service student -teacher).

"Generally, my students are behaving well, however, there are still few especially the ones who are performing poorly in my assignments tend to disturb their fellow students when I am teaching" (BSC, 3rd year student).

"Last week, I had the most terrible experience in my form two classroom. As I was teaching, I noticed that two boys, backbenchers (aged between 13-15) were fighting. I called them in front of the class and told them to kneel down. One of the boys refused and ran away. I have ordered him not to attend my lessons till he apologizes to me" (Postgraduate student-teacher).

" I teach Geography in forms two [ages between 13-15] and four[15-17 years]. The form two, especially boys, are too disturbing [sic] than their brothers in form four. I

\section{Emerging themes}

1. Boys disrupts more than girls

1. Inattentiveness

2. Weak students

3. Teacher attributions

1. Boys are involved in physical violence

2. Teaching is stressing

3. Punitive strategies

4. Non-compliance 
spend most of my time correcting this and that [misbehaviour] instead of teaching. Host teachers insist that I plan my practicum assessment with the form fours who seem more mature and well behaving." and gender

2. Classroom level

3. Practicum is for Grading

4. Poor mentorship

Source: Field data (March 2018)

Findings from Table 5 show that although lessons in Tanzania secondary schools are largely dominated by mild or common occurring disruptive behaviours, there are moments when more highly disruptive behaviours such as fighting in the classrooms are reported. Boys tend to engage more in all types of disruptive behaviours ranging from mild to severe than girls. Additionally, student-teachers attributed misbehaviour to students' inability (poor performance in school subjects), classroom level and age of the students. Implying that adolescent boys are more likely to engage in disruptive behaviours that are aggravated by attention seeking and fighting is opted as the way to resolve conflicts (Rayment, 2006; De wet, 2003).

It can also be deduced from the excerpt above that many behavioural problems reported by student-teachers were partly due to student-teachers inability to communicate effectively during classroom instructions. They were also caused by a lack of or poor mentoring of student-teachers by experienced teachers and by "the practicum grading syndrome", whereby student-teachers consider their practicum as an avenue to be assessed and assigned a grade for their program of study rather than seeing it as a moment for practicing and learning how to teach effectively. However, some studies also suggest that students may become involved in disruptive behaviours because of boredom or demotivation when the teacher is not delivering the lesson according to students' expectations (Gibson et al., 2018).

Drawing on these findings, it is important that teacher trainers and educators in teacher education emphasize equipping novice teachers with the pedagogical skills and competencies necessary in managing classrooms and know how to deal effectively with disruptive behaviours. Ensuring effective mentorship of student-teachers during practicum is one way of doing this. 


\section{Student-teachers' Strategies in Dealing with Disruptive Behaviour in the Classrooms}

In order to understand how student-teachers dealt with disruptive behaviours, participants were asked to indicate strategies they employed to address disruptive behaviours in the classrooms. These are reflected in Table 6 below:

Table 6: Strategies towards addressing behavioural problems in the classroom (by frequencies and percentages)

\begin{tabular}{|c|c|c|}
\hline Behaviour & Employed strategies & $\begin{array}{l}\text { Teachers using the } \\
\text { strategy }\end{array}$ \\
\hline \multirow[t]{3}{*}{ Side conversation } & Telling the student to keep quiet & $21(30 \%)$ \\
\hline & Suspending the student from the lesson & $3(4 \%)$ \\
\hline & Ignoring the student & $3(4 \%)$ \\
\hline \multirow[t]{3}{*}{ Bullying } & Suspending the student from the lesson & $13(19 \%)$ \\
\hline & Students bring their parents & $14(20 \%)$ \\
\hline & Use corporal punishment (caning) & $4 \quad(6 \%)$ \\
\hline \multirow{3}{*}{$\begin{array}{l}\text { Student abusing the } \\
\text { teacher }\end{array}$} & Apply corporal punishment & $20(29 \%)$ \\
\hline & Report the student to disciplinary office & $2 \quad(3 \%)$ \\
\hline & $\begin{array}{l}\text { Students bring parents to school disciplinary } \\
\text { committee }\end{array}$ & $3 \quad(4 \%)$ \\
\hline \multirow{4}{*}{$\begin{array}{l}\text { Using mobile phones } \\
\text { during the lesson }\end{array}$} & Suspending student from the lesson & $2(3 \%)$ \\
\hline & Confiscating the phone from the student & $17(24 \%)$ \\
\hline & Report the student to the disciplinary office & $12(17 \%)$ \\
\hline & $\begin{array}{l}\text { Orienting students on the proper use of mobile } \\
\text { phone }\end{array}$ & $5 \quad(7 \%)$ \\
\hline \multirow{3}{*}{$\begin{array}{l}\text { Listening to music while } \\
\text { the teacher is teaching }\end{array}$} & Report the student to the discipline office & $6 \quad(9 \%)$ \\
\hline & Take away the /Mp3/iPod & $12(17 \%)$ \\
\hline & Teach the students the effects of listening to music & $10(14 \%)$ \\
\hline
\end{tabular}


during the lesson

Student speaking without permission

Facebooking

Physical aggressiveness towards fellow students

Student text messaging while the teacher is teaching

Students fighting one another

Sleeping in the classroom

Punish the student (corporal punishment)

Suspend the student from the lesson

Find out why the student is sleeping

Students bring their parents to the schools' disciplinary committee

Suggest to the committee to expel students from studies

Reminding students on classroom rules and

$2(3 \%)$

$21(30 \%)$

$11(15 \%)$

$8(11 \%)$

$15(21 \%)$

$6 \quad(9 \%)$

$18(26 \%)$

$10 \quad(14 \%)$

$1 \quad(1 \%)$

19 (27\%)

$6 \quad(9 \%)$

$4 \quad(6 \%)$

Preventing other students Send the student outside the classroom

$21(30 \%)$

$1(1 \%)$

$5 \quad(7 \%)$

$4 \quad(6 \%)$ 
from concentrating in the Modifying student's sitting plan lesson
$22(31 \%)$

$4 \quad(3 \%)$
$15(21 \%)$

$12(17 \%)$

$1 \quad(1 \%)$
Threatening to harm the teacher
Report the student to the discipline office

Punish the student

Suspend the student from the lesson
Student monopolizing

class discussion
Encourage the student

Ignore the student

Appoint the student as a class leader
$8(11 \%)$

$6 \quad(9 \%)$

$8(11 \%)$

Source: Field data (March 2018)

Findings from Table 6 indicate that there is no difference between how student-teachers responded to mild or common occurring disruptive behaviours like students engaging in side conversations to the most serious ones like fighting. The table illustrates further that the student-teachers responded to disruptive behaviours mainly by using punitive/ reactive strategies as opposed to rewards and students' self-regulation/control techniques. The student-teachers seemed to have considered the disciplinary office to be the principal means of addressing classroom disruptive behaviours. Hence, measures such as reporting students to the disciplinary office or reporting students to the disciplinary committee received higher frequencies in this study.

The implications of these findings are twofold; first, teacher preparatory programmes need to integrate classroom management skills as key curricula component. Secondly, because the 2014 Tanzania Educational Training Policy (ETP) prohibits teachers from applying corporal punishment to students, except with the permission of headteacher, student-teachers directed disciplinary matters to the responsible office. Nonetheless, the findings show that some student -teachers still used corporal punishment on students, an indication of a mismatch between the policy requirements and teachers' practices. The persistence of punitive measures in addressing disruptive behaviours in schools indicates that it might be deep-rooted in the school system. Changing teachers' practices, however, demands altering the educational and training policy in the first place. Drawing from 
these findings, it is positive that both the pre-and in-service teachers know that it is difficult to teach and learn effectively in a classroom dominated by disruptive behaviours. However, as the literature suggests it is also challenging, if not impossible, to address classroom disruptive behaviours by relying on techniques that aim to impose teachers' control to obtain submissiveness of the learners (Mahvar, Farahani, \& Aryankhesal, 2018; Osher, Bear, Sprague \& Doyle, 2010; Sullivan, Johnson, Owen \& Conway, 2014).

\section{Maintaining Appropriate Behaviours to Improve Learning in the Classroom}

Using a questionnaire, student-teachers were asked to indicate strategies they employed to foster learning. They were at the same time required to comment on the suitability of those strategies towards nurturing appropriate behaviours and maintaining effective learning in the classroom. The table below illustrates.

Table 7. Participants' responses on use and suitability of various strategies to address classroom disruptive behaviours

\begin{tabular}{|c|c|c|}
\hline Strategy & Use & Suitable \\
\hline State clearly classroom/school rules and regulations & $14 \quad(20 \%)$ & $18(26 \%)$ \\
\hline Teach social skills & $13(19 \%)$ & $9(13 \%)$ \\
\hline Counselling & $7 \quad(10 \%)$ & $7(10 \%)$ \\
\hline Create conducive learning environment & $50(71 \%)$ & $40(57 \%)$ \\
\hline $\begin{array}{l}\text { Use other forms of punishment (beside what?) on disruptive } \\
\text { students }\end{array}$ & $46(66 \%)$ & $50(71 \%)$ \\
\hline Reward /reinforce well behaving students & $21(30 \%)$ & $19(27 \%)$ \\
\hline Teachers as role models & $16(23 \%)$ & $8 \quad(11 \%)$ \\
\hline Suspend disruptive students from the lesson & $36(51 \%)$ & $41(59 \%)$ \\
\hline Get students engage students with tasks & $18(26 \%)$ & $16(23 \%)$ \\
\hline Involve students in extra-curricular activities & $4 \quad(6 \%)$ & $3(4 \%)$ \\
\hline Apply corporal punishment & $60(86 \%)$ & $58(83 \%)$ \\
\hline
\end{tabular}


Restrict mobile phone usage in the classroom

Involve parents

Inform students about the consequences of disrupting

Report the student to the disciplinary office

Develop positive student-teacher relationship

Regular meeting with students

Apply learner centred teaching approaches
$58(83 \%)$

$7 \quad(10 \%)$

$6 \quad(9 \%)$

$45(64 \%)$

$17(24 \%)$

$14(20 \%)$

$10 \quad(14 \%)$
$47 \quad(67 \%)$

$5(7 \%)$

$1 \quad(1 \%)$

$42(60 \%)$

$11(16 \%)$

$4 \quad(6 \%)$

$2(3 \%)$

Source: Field data (March 2018)

Findings in Table 7 show that the majority of the participants used corporal punishment $(86 \%)$, restricted mobile phone usage in the classroom (83\%), created a conducive learning environment $(71 \%)$ and used other forms of punishment to disrupting students (66\%). Commenting on the suitability of the strategies, $83 \%$ of the participants reported the use of corporal punishment, $71 \%$ other forms of punishment, $67 \%$ restricting mobile phone usage in the classroom and $64 \%$ reporting disruptive students to the disciplinary office as the most suitable strategies or techniques to address students' behavioural problems.

The findings above suggest that student-teachers used more restrictive and control measures than supportive strategies to address disruptive behaviours. The punitive strategies might seem to be working because students were forced to maintain order and comply with classroom rules and regulations that were set forth by teachers or the school administration. This in turn, perpetuated the "teacher centred classrooms" where students remained recipients of orders from the teachers. As reported in the literature, this sort of learning environment makes students less engaged in the lessons due to teachers' authoritarianism and reliance on classroom rules and regulations as means to curb disruptive behaviours (Booth, 2017; Mugabe \& Maposa, 2007).

\section{Discussion}

The fact that effective teaching is partly influenced by how best teachers can minimize disruptive behaviours from occurring becomes a critical variable for teacher training programmes around the world. To understand how classroom management skills are put into practice during practicum, this study explored student-teachers' experiences and the strategies they used to manage classroom 
disruptive behaviours in Tanzania secondary schools. Although there is a dearth of literature around this topic on Tanzania, the regional and international literature reviewed challenge the dominance and appropriateness of punitive strategies and techniques (as evidenced in Tanzania classes) in addressing misbehaviours in schools (Mahvar, Farahani, \& Aryankhesal, 2018; Osher, Bear, Sprague \& Doyle, 2010; Sullivan, Johnson, Owen \& Conway, 2014; Wubbels, 2011). Instead, strategies focusing on supporting and empowering students with self- regulation and control and with problem-solving skills are recommended in pre-and in-service teacher programmes (Booth, 2017; Brandon et al., 2014; Woodcock \& Reupert, 2017). Recent studies recommend various behaviour management approaches as a replacement to punitive or reactive strategies predominantly in Tanzania and other developing countries (Matsoga, 2003; Njoroge \& Nyabuto, 2014; Semali \& Vumilia, 2016). These recommended strategies include restorative practices (Drewery, 2014; McCluskey, 2018; Wearmouth \& Berryman, 2012), pro-active strategies (CluniesRoss, Little \& Kienhuis, 2008; Ellis \&Tod, 2013) and holistic/ecosytemic (Kourkoutas, 2012) as alternative behaviour management approaches in schools. Altogether, these strategies underscore the need for several essential elements for effective management of disruptive behaviours, including, a). positive student-teacher relationship, student-teacher mutual communication and interaction, b). reciprocal accountability, respect and support and focus on the problem and not the student/person as being the problem, and c). contextualizing disruptive behaviours. The latter implies that the context, either social, cultural, or environmental, is key to determining what is the un/acceptable behaviour and what type of learning that is valued and desirable. The last essential element is, d). focus on preventive measures rather than waiting for inappropriate behaviours to occur before (re)acting (Clunies-Ross, Little \& Kienhuis, 2008; Drewery, 2014; Ellis \& Tod, 2013; Kourkoutas, 2012; McCluskey, 2018; Wearmouth \& Berryman, 2012).

\section{Conclusion}

The persistence of disruptive behaviours in Tanzania secondary schools, as elsewhere, calls for new approaches in classroom behaviour management skills. These new skills and approaches need to be reflected in teacher preparatory programmes to equip future teachers with the required competencies to address the causes and consequences of disruptive behaviours. To delay attending to disruptive behaviours may interfere with socio-emotional functioning of students past their time at school and into adulthood. Hence, this should make it a matter of urgency to policy makers and 
educators. Moreover, practicums as avenues where these classroom management practices are put into practice need to be paired with effective mentorship by host teachers, university supervisors, and other relevant stakeholders.

As evidenced through the findings of this study, participants perceived both mild and severe disruptive behaviours as a hindrance to teaching and learning. They held the view that appropriate student classroom behaviour is a precursor to effective teaching and learning. However, the reactive strategies in dealing with disrupting students they adopt negates the possibility of a conducive learning environment. As such, this study advocates that, like any other training for competencies, appropriate behaviours need to be nurtured rather than simply demanded. This presupposes that, while students may feel that adopting the punitive strategy is necessary to prevent disruptive behaviours in the classroom, it is more important to teach and nurture appropriate classroom behaviours through supportive strategies such as tolerance, effective feedback and by creating positive student-teacher relations. To achieve this, educators must spend some time to teach, reinforce and set guidelines jointly with their students on how to maintain appropriate classroom behaviours. Drawing on the findings of this study and the related literature, the need to equip teacher trainees with knowledge about disruptive behaviour and how to address them most effectively is a necessity to which we draw the attention of Tanzanian teachers and other stakeholders in teacher education.

\section{References}

Atici, M. (2007). A small-scale study on student teachers' perceptions of classroom management and methods for dealing with misbehaviour. Emotional and Behavioural Difficulties, 12(1), 15-27.

Baker, Ö. E., \& Tanrikulu, İ. (2010). Psychological consequences of cyber bullying experiences among Turkish secondary school children. Procedia-Social and Behavioral Sciences, 2(2), 2771-2776.

Booth S.S. (2017). Planned ignoring. In: Geng G., Smith P., Black P. (eds), The challenge of teaching (pp 181-187). Springer, Singapore.

Braun,V. \& Clarke, V. (2006). Using thematic analysis in psychology. Qualitative Research in Psychology, 3 (2), 77-101, DOI: 10.1191/1478088706qp063oa. 
Brandon, M., Glaser, D., Maguire, S., McRory, E., Lushey, C. and Ward, H. (2014) Missed opportunities: Indicators of neglect-what is ignored, why, and what can be done?'. Research Report, Department for Education. DFE-RR404. Accessed on 16th June 2020 from

https://assets.publishing.service.gov.uk/government/uploads/system/uploads/attachment_dat a/file/379747/RR404_-_Indicators_of_neglect_missed_opportunities.pdf.

Bromfield, C. (2006). PGCE secondary trainee teachers and effective behaviour management: An evaluation and commentary. Support for Learning, 21(4), 188-193.

Brown, B., \& Marin, P. (2009). Adolescents and electronic media: Growing up plugged in. Child Trends Research Brief, 29.

Bryman, A. (2016). Social Research Methods. $5^{\text {th }}$ edition, Oxford: Oxford University Press.

Brouwers, A., \& Tomic, W. (2000). A longitudinal study of teacher burnout and perceived selfefficacy in classroom management. Teaching and Teacher Education, 16 (2), 239-253. doi:10.1016/S0742-051X(99)00057-8.

Clunies-Ross, P., Little, E., \& Kienhuis, M. (2008). Self-reported and actual use of proactive and reactive classroom management strategies and their relationship with teacher stress and student behaviour. Educational Psychology, 28(6), 693-710.

Cooperkline, J. (2009). School absenteeism, disruptive classroom behaviour, and negative family processes in a sample of court-involved youth. Doctoral dissertation, The Ohio State University.

Creswell, J. W. (2015). Educational research: Planning, conducting and evaluating quantitative and qualitative research (4th ed.). New Jersey: Pearson Education, Inc.

De Wet, C. (2003). Eastern Cape educators' perceptions of the causes and the scope of school violence. Acta Criminologica: African Journal of Criminology \& Victimology, 16(3), 89106.

Drewery, W. (2014). Restorative practice in New Zealand schools: Social development through relational justice. Educational Philosophy and Theory, 48(2), 191-203. 
Ellis, S., \& Tod, J. (2013). Behaviour for learning: Proactive approaches to behaviour management. Routledge.

Finn, J.D., Fish, R.M., \& Scott, L.A. (2008). Educational sequelae of high school misbehaviour. The Journal of Educational Research, 101(5):259-274 DOI: 10.3200/JOER.101.5.259-274.

Friedman, I. A., \& Farber, B. A. (1992). Professional self-concept as a predictor of teacher burnout. Journal of Educational Research, 86 (1), 28-35.

Ghazi, S. R., Shahzada, G., Tariq, M., \& Khan, A. Q. (2013). Types and causes of students' disruptive behavior in classroom at secondary level in Khyber Pakhtunkhwa, Pakistan. American Journal of Educational Research, 1(9), 350-354.

Mahvar, T., Ashghali Farahani, M., \& Aryankhesal, A. (2018). Conflict management strategies in coping with students' disruptive behaviors in the classroom: Systematized review. Journal of Advances in Medical Education \& Professionalism, 6(3), 102-114.

Hastings, R. P., \& Bham, M. S. (2003). The relationship between student behaviour patterns and teacher burnout. School psychology international, 24(1), 115-127.

Johnson, R. B., \& Christensen, L. (2017). Educational research: Quantitative, qualitative, and mixed approaches (6th ed.). Thousand Oaks, CA: Sage.

Joffe, H. (2012). Thematic analysis. In D. Harper and A. Thompson(eds), qualitative research in mental health and psychotherapy: An introduction for students and practitioners, Chichester: Wiley-Blackwell, pp. 2009-224.

Joyce-Gibbons, A., Galloway, D., Mollel, A., Mgoma, S., Pima, M., \& Deogratias, E. (2018). Successful transition to secondary school in Tanzania: What are the barriers? Journal of International Development, 30 (7), 1142-1165. doi:10.1002/jid.3304.

Kourkoutas, E. E., \& Wolhuter, C. C. (2013). Handling learner discipline problems: A psychosocial whole school approach. koers, 78(3), 1-8.

Kowalski, R. M., \& Limber, S. P. (2007). Electronic bullying among middle school students. Journal of adolescent health, 41(6), S22-S30.

Levin, J. \& Nolan J.F. (1996). Principals of classroom management: a professional decisionmaking model. London: Allyn \& Bacon. 
Matsoga, J. T. (2003). Crime and school violence in Botswana secondary education: The Case of molding senior secondary school (Unpublished doctoral dissertation). Ohio University.

McCluskey G. (2018) Restorative approaches in schools: Current practices, future directions. In: Deakin J., Taylor E., Kupchik A. (eds), The Palgrave International Handbook of school discipline, surveillance, and social control, (pp573-593). Palgrave Macmillan, Cham

Mugabe, M.J. \& Maposa, A.D. (2007). Methods of curbing learner misconduct in Zimbabwean secondary schools. Proceedings of the First International Conference on Learner Discipline at the North-West University, Potchefstroom Campus. 02 - 04 April 2007, 1 - 19.

Närhi V, Kiiski T, Savolainen H. (2017). Reducing disruptive behaviours and improving classroom behavioural climate with class-wide positive behaviour support in middle schools. British Educational Research Journal. 43 (6):1186-205.

Nene, F. Z. (2013). The challenges of managing learner discipline: the case study of two schools in Pinetown district (Masters dissertation).

Njoroge, P. M., \& Nyabuto, A. N. (2014). Discipline as a factor in academic performance in Kenya. Journal of Education and Social Research, 4(1), 289-307. http://dx.doi.org/10.5901/jesr.2014.v4n1p289.

O’Brennan, L. M., Bradshaw, C. P., \& Furlong, M. J. (2014). Influence of classroom and school climate on teacher perceptions of student problem behaviour. School Mental Health, 6(2), 125-136. doi:10.1007/s12310-014-9118-8.

Osher, D., Bear, G. G., Sprague, J. R., \& Doyle, W. (2010). How can we improve school discipline? Educational Researcher, 39(1), 48-58. doi: 10.3102/0013189x09357618 http://dx.doi.org/10.3102/0013189X09357618.

Oliver, M. R. \& Reschly, J. D. (2007). Effective classroom management teacher preparation and professional development. Washington D.C: National comprehensive centre for teachers.

Rayment, T. (2006). Managing boys’ behaviour. New York: MPG Books Ltd.

Rose, L. C., \& Gallup, A. M. (2005). The $37^{\text {th }}$ annual Phi Delta Kappa/Gallup poll of the public attitudes toward the public schools. Phi Delta Kappan, 87(1), 41-57. 
Semali, L. M. \& Vumilia, P.L. (2016). Challenges facing teachers' attempts to enhance learners' discipline in Tanzania secondary schools. World Journal of Education, 6 (1) 50-67.

Shapka, J. D., Onditi, H. Z., Collie, R. J., \& Lapidot-Lefler, N. (2018). Cyberbullying and cybervictimization within a cross-cultural context: A study of Canadian and Tanzanian adolescents. Child development, 89(1), 89-99.

Shavega, T. J., van Tuijl, C., \& Brugman, D. (2015). Teachers' perception of children's behavioural adjustment in Tanzanian pre-primary schools and their relationship to teachers' cultural beliefs regarding obedience, cooperation, and play. Infants \& Young Children, 28(1), 88108. doi:10.1097/IYC.0000000000000026.

Shariff, S. \& Johnny, L. (2007). Cyber-libel and cyber-bulling: Can schools protect student reputations and free expression in virtual environment? Education and Law Journal, 16(3), 307-342.

Shinn, M. R., Ramsey, E., Walker, H. M., Stieber, S., \& O'Neill, R. E. (1987). Antisocial behaviour in school settings: Initial differences in an at-risk and normal population. The Journal of Special Education, 21, 69-84.

Stewart, D. (2004). Learner discipline: An Australian perspective. Koers, 69(2), 317-335.

Stough, L. (2006). The place of classroom management and standards in teacher education. In C.M. Evertson \& C.S. Weinstein (Eds.), Handbook of classroom management: Research, practice, and contemporary issues (pp. 909-924). Mahwah: Lawrence Erlbaum Associates.

Sullivan, A. M., Johnson, B., Owens, L., \& Conway, R. (2014). Punish them or engage them? Teachers' views of unproductive student behaviours in the classroom. Australian Journal of Teacher Education, 39(6), 43-56.

Tulley, M., \& Chiu, L. H. (1995). Student teachers and classroom discipline. The Journal of Educational Research, 88(3), 164-171.

Reupert, A., \& Woodcock, S. (2011). Canadian and Australian pre-service teachers' use, confidence and success in various behaviour management strategies. International Journal of Educational Research, 50(5-6), 271-281. 
Vitto, J. M. (2003). Relationship-driven classroom management: Strategies that promote student motivation. Corwin Press.

Walker, H.M., Ramsey, E., \& Gresham, F.M. (2004). Antisocial behaviour in schools: Evidencebased practices. Wadsworth: Thomson Learning.

Woodcock, S., \& Reupert, A. (2017). A tale from three countries: the classroom management practices of pre-service teachers from Australia, Canada and the United Kingdom. Teacher Development, 21(5), 655-667.

Wubbels, T. (2011). "An international perspective on classroom management: What should prospective teachers learn?” Teaching Education, 22 (2): 113-131.

Yusoff, W.M.W, Mansor N. (2016). The effectiveness of strategies used by teachers to manage disruptive classroom behaviors: A case study at a religious school in Rawang, Selangor, Malaysia. IIUM Journal of Educational Studies, 4(1):133-50 . 